\title{
INTERNATIONAL LEGAL COOPERATION AND THE PRINCIPLE OF EQUALITY AMONG NATIONS: LESSONS FROM CRIMINAL LAW AND PROCEDURE
}

\author{
Lissa Griffin ${ }^{1}$ \\ Elisabeth Haub School of Law at Pace University, United States
}

\begin{abstract}
International efforts to achieve fair, efficient and reliable criminal justice systems can benefit from the openminded exchange of ideas, values, and choices among nations, each respecting the other's contributions. Obstacles exist to the United States' fully joining this effort in its insistence on American exceptionalism and its continued reliance on unreliable evidence.
\end{abstract}

Keywords: International Legal cooperation, Equality among nations, criminal law.

Contents: 1 Introduction. 2 The Durability of American Exceptionalism. 3 Unreliable Factfinding. 4 Conclusion.

\section{INTRODUCTION}

In the area of criminal law and procedure, international legal cooperation is important in two respects. First, because virtually all criminal justice systems face the same concerns in balancing fairness and efficiency, ${ }^{2}$ each system can benefit from learning about the experiences of and developments in other countries. ${ }^{3}$ Second, nations can and should collaborate to address international criminal law problems through treaties and other joint efforts. ${ }^{4}$ On both fronts, successful cooperation depends at least in part on an understanding of the commonality of the issues and challenges and an openness to learning how other systems deal with these problems. Another essential element is a trust in the integrity of cooperating partners in their efforts to

\footnotetext{
${ }^{1}$ Professor of Law and Director of the Criminal Practice Concentration, Elisabeth Haub School of Law at Pace University, White Plains, N.Y. lgriffin@law.pace.edu

${ }^{2}$ See Herbert Packer, The Limits of THE Criminal SAnction (Stanford University Press 1968) (examining the rationale of the criminal sanction).

${ }^{3}$ See, e.g., Richard S. Frase, Comparative Criminal Justice As A Guide to American Law Reform: How do the french do it, how can we find out, and why should we care?, 78 CAL. L. REV. 539, 544 (1990) (surveying "the prospects for future reformoriented research on continental criminal procedure").

4 See, e.g., Treaties and Agreements, U.S. DEP'T OF STATE (Mar. 7, 2012), https://20092017.state.gov/j/inl/rls/nrcrpt/2012/vol2/184110.htm (listing countries in which the Department of Justice has negotiated Mutual Legal Assistance Treaties, allowing for the exchange of evidence and information in criminal and related matters).
} 
improve their criminal justice systems. The requirements of open-mindedness and trust allow for equal and productive cooperation internationally.

Currently, obstacles exist that interfere with the ability of the United States to engage in international legal cooperation. First, the United States is limited in its ability to learn from other systems because of the notion of American exceptionalism. ${ }^{5}$ Second, from the perspective of other nations, the United States is an outlier in the international criminal justice community. Wariness and distrust stem from its refusal to join or join fully in international treaties, its continued imposition of the death penalty, ${ }^{6}$ and its mass incarceration system. Moreover, international concerns arise from US courts' reliance on procedural and evidentiary rules that undermine the reliability of fact-finding and an adversarial system that often devalues truth and accuracy. These factors have not only interfered with the United States' historic leadership role, but have sowed distrust that prevents the United States from being a successful partner in international cooperation.

\section{The DURABILITY OF AMERICAN EXCEPTIONALISM}

"American exceptionalism" is a phrase originally coined in the 1830 s by Alexis de Tocqueville, who observed that America seemed "exceptional" as a large, new democracy that practical success over the pursuit of the arts and sciences for their own sakes. ${ }^{7}$ The term has come to include the much larger idea that based on its free-market democracy, its ideology of liberty, equal opportunity (as opposed to equality of outcomes), and individualism, and its history, size, geography, and constitutional political structure, the United States occupies a special place in the world and is exempt from international norms. ${ }^{8}$ American exceptionalism manifests itself in several ways: exempting itself from the provisions of international human rights and other treaties; a double standard, by which the United States uses standards to judge

\footnotetext{
${ }^{5}$ Stephen Gardbaum, The Myth and the Reality of American Constitutional Exceptionalism, 107 Mich. L. REv. 391 (2008); Steven G. Calabresi, A Shining City on A Hill: American Exceptionalism and the Supreme Court's Practice of Relying on Foreign Law, 86 B.U. L. Rev. 1335, 1335 (2006); Randy E. Barnett, The Separation of People and State, 32 HARV. J.L. \& PuB. PoL'y 451, 451 (2009).

${ }^{6}$ Jordan M. Steiker, The American Death Penalty: Constitutional Regulation As the Distinctive Feature of American Exceptionalism, 67 U. Miami L. Rev. (2) 329, 329 (2013); William W. Berry III, American Procedural Exceptionalism: A Deterrent or A Catalyst for Death Penalty Abolition?, 17 CORNELL J.L. \& PUB. POL'Y 481 (2008); Roper v. Simmons, 543 U.S. 551,575 (2005) ("Our determination that the death penalty is disproportionate punishment for offenders under 18 finds confirmation in the start reality that the United States is the only country in the world that continues to give official sanction to the juvenile death penalty.").

${ }^{7}$ See Alexis de Toqueville, Democracy in America (Harvey C. Mansfield \& Delba Winthrop eds. \& trans., Univ. of Chi. Press 2000) (1840).

${ }^{8}$ Anu Bradford \& Eric A. Posner, Universal Exceptionalism in International Law, 52 Harv. InT'L L. J. (1) 1, 4-5 nn. 5-10 (2011) [hereinafter "Bradford"].
} 
itself and countries with whom it has good relationships; and a form of legal isolation - refusing to acknowledge the laws of other countries or international tribunals. ${ }^{9}$ The United States is the only Western democracy that regularly refuses to adhere to international human rights treaties. ${ }^{10}$ It is also the only western democracy to retain the death penalty, which has resulted in the refusal of other countries to extradite their citizens to the United States. ${ }^{11}$

\section{UNRELIABLE FACTFINDING}

The United States seems to systemically devalue truth through a wilingness of its courts to admit and rely on unreliable evidence. The U.S. Supreme Court itself has been criticized repeatedly for allowing the explosive growth of amicus submissions that frequently are filed by partisan organizations and contain partisan, or otherwise unreliable, "facts." 12 Those facts then find their way into Supreme Court decisions that are binding on all US courts. In addition, despite the alarm sounded by the National Academy of Sciences report about the unreliability of several well-known forensic techniques and crime lab scandals, state and federal courts continue to admit and rely on unsound and unreliable scientific evidence. ${ }^{13}$ In some cases, wrongful convictions based on unreliable proof are corrected after many years. ${ }^{14}$ But the existence of procedural hurdles and a rigid commitment to the doctrine of finality permit unsound convictions to stand. ${ }^{15}$

The systemic devaluation of truth has also been manifested by recent public legal discourse that has been dominated by misinformation. Visible and publically outspoken US lawyers such as Rudolph Guiliani, the President's lawyer, and William Barr, his Attorney General, have been accused misrepresenting the truth. Mr. Giuliani has been exposed for

\footnotetext{
9 See American Exceptionalism and Human Rights 3-9 (Michael Ignatieff ed., Princeton University Press) (2005) (discussing American Exceptionalism).

${ }^{10}$ Bradford, supra n. 7, at 4-5.

11 Max Fisher, Map: Which Countries Use the Death Penalty?, THE ATLANTIC (July 6, 2011), https://www.theatlantic.com/international/archive/2011/07/map-which-countries-use-the-death-penalty/241490/. For a history of abolition of the death penalty among western democracies, see Carol S. Steiker, Capital Punishment and American Exceptionalism, AMERICAN EXCEPTIONALISM AND HuMAN Right, supra note 8, at 59.

12 Allison Orr Larsen, Constitutional Law in an Age of Alternative Facts, 93 N.Y.U. L. Rev. 175, 175 (2018).

13 Radley Balko, The criminal justice system also has an 'alternative facts' problem, WASH. Post (Jan. 31, 2019), https://www.washingtonpost.com/opinions/2019/01/31/criminal-justice-system-also-has-an-alternative-facts-problem/.

14 See, eg., Commonwealth v. Ross, No. 1738 WDA 2018, 2019 WL 6211324 (Pa. Super. Ct. Nov. 21, 2019) http://www.pacourts.us/assets/opinions/Superior/out/J-S55007-19m\%20-\%2010423159687925902.pdf; Commonwealth v. Kunko, No. 482 C 1991 (Pa. Super. Oct. 29, 2010), https://reason.com/wp-content/uploads/assets/db/13037486936458.pdf; Howard v. State, 945 So. 2d 326 (Miss. 2006) (reimposing the death sentence on a defendant convicted using bite mark evidence, with the Mississippi Supreme Court writing "Just because [the expert] has been wrong a lot, does not mean, without something more, that he was wrong here.").

15 Radley Balko, Bad science puts innocent people in jail - and keeps them there, WAsH. Post. (Mar. 21, 2018), https://www.washingtonpost.com/outlook/bad-science-puts-innocent-people-in-jail--and-keeps-themthere/2018/03/20/f1fffd08-263e-11e8-b79d-f3d931db7f68_story.html ("Even once a field of forensics or a particular expert has been discredited, the courts have made it extremely difficult for those convicted by bad science to get a new trial.").
} 
stating untruths, and directly contradicting his own prior statements. ${ }^{16} \mathrm{He}$ has stated publically that "truth isn't truth." 17 William Barr has perpetuated misinformation by his attempt to misconstrue the Mueller Report's findings and then claiming that the White House fully cooperated with the investigation when it did not. ${ }^{18} \mathrm{He}$ also delegitimized the results of a full factual investigation by the inspector general. ${ }^{19}$ Similarly, Kelly Anne Conway, counsel to the President, is responsible for creating the phrase "alternative facts," an obvious oxymoron, and for legitimizing it. ${ }^{20}$

\section{CONCLuSion}

International legal cooperation on criminal justice issues presents the opportunity for the United States to contribute much and to help solve problems that cross international borders. Short of major changes in domestic law, which are beyond the scope of this article, several possibilities exist for restoring the role of the United States as an equal partner in international legal cooperation. First, the Supreme Court should continue Retired Justice Anthony Kennedy's willingness to refer to international criminal justice standards in interpreting the US bill of rights. ${ }^{21}$ Other, lower courts, would follow suit. Indeed, a contributing factor to Justice Kennedy's inclusion of international standards was his involvement in international judicial conferences and judicial and scholarly collaborations. ${ }^{22}$ This sort of cross-pollination of the judiciary - among judges at every level -- is invaluable. Second, an attempt could be made to broaden the perspective of US law students. While there is an organization for students interested in international law, there is no organization through

\footnotetext{
${ }^{16}$ See Bennett L. Gershman, Rudolph Giuliani and the Ethics of Bullshit, 57 DuQ. L. REv. 293 (2019) (collecting list of untruths).

17 Rebecaa Morin \& David Cohen, Giuliani: 'Truth isn't truth', POLITICO (Aug. 19, 2019), https://www.politico.com/story/2018/08/19/giuliani-truth-todd-trump-788161.

18 Bill McCarthy, Latest Mostly False Fact-Checks On William Barr, POLTICFACT (Dec. 11, 2019), https://www.politifact.com/factchecks/list/?category=\&ruling=barely-true\&speaker=william-barr (last visited Feb. 26, 2020) ("The Inspector General's report now makes clear that the FBI launched an intrusive investigation of a U.S. presidential campaign on the thinnest of suspicions."); John Kruzel, Latest False Fact-Checks On William Barr, POLTICFACT (April 22, 2019), https://www.politifact.com/factchecks/list/?category=\&ruling=false\&speaker=william-barr (last visited Feb. 26, 2020) ("The white house fully cooperated with the special counsel's investigation").

${ }^{19}$ Statement of Attorney General William P. Barr on the Inspector General's Report of the Review of Four FISA Applications and Other Aspects of the FBI's Crossfire Hurricane Investigation, DEP'T OF JUST. (Dec. 9, 2019), https://www.justice.gov/opa/pr/statement-attorney-general-william-p-barr-inspector-generals-report-review-four-fisa.

${ }^{20}$ Rebecca Sinderbrand, How Kellyanne Conway ushered in the era of 'alternative facts', WASH. Post. (Jan. 22, 2017), https://www.washingtonpost.com/news/the-fix/wp/2017/01/22/how-kellyanne-conway-ushered-in-the-era-of-alternativefacts/.

${ }^{21}$ See, e.g., Roper v. Simmons, 543 U.S. 551 (2005) ("It does not lessen our fidelity to the Constitution or our pride in its origins to acknowledge that the express affirmation of certain fundamental rights by other nations and peoples simply underscores the centrality of those same rights within our own heritage of freedom.").

${ }^{22}$ See, Jeffrey Toobin, Swing Shift: How Anthony Kennedy's Passion for Foreign Law Could Change the Supreme Court, The New Yorker, Sept. 12, 2005 (describing Justice Kennedy's extensive participation in such events).
} 
which law students interested in criminal law and procedure can share information, developments, and insights or discuss comparative criminal procedure issues. Another possibility would be to increase the availability of international externships, through which students are exposed to and participate in the domestic criminal justice systems of other countries. Isolation and exceptionalism will not result in successful international cooperation, and trust in the integrity of cooperating nations is essential.

\section{REFERENCE LIST}

A. De Toqueville, Democracy in America (Harvey C. Mansfield \& Delba Winthrop eds. \& trans., Univ. of Chicago Press 2000) (1840).

A. Orr Larsen, Constitutional Law in an Age of Alternative Facts, 93 NEW YORK UNIVERSITY LAW REVIEW - N.Y.U. L. REV. 175-248 (2018).

AmERiCAN EXCEPTIONALISM AND Human Rights 3-9 (Michael Ignatieff ed., Princeton University Press) (2005).

A. Bradford \& E. A. Posner, Universal Exceptionalism in International Law, 52 HARVARD INTERNATIONAL LAW JOURNAL - HARV. INT'L L. J. (1) 1-54 (2011).

B. L. Gershman, Rudolph Giuliani and the Ethics of Bullshit, 57 DuQUESNE LAW REVIEW DUQ. L. REV. 293-308 (2019).

B. McCarthy, Latest Mostly False Fact-Checks On William Barr, POLTICFACT (Dec. 11, 2019), $\quad$ https://www.politifact.com/factchecks/list/?category=\&ruling=barelytrue\&speaker=william-barr.

C. S. Steiker, Capital Punishment and American Exceptionalism, AMERICAN EXCEPTIONALISM AND HuMAN RIGHT (Michael Ignatieff ed., Princeton University Press) 57-89 (2005).

H. PACKeR, THE Limits OF THE CRIMINAL SANCTION (Stanford University Press 1968).

J. Kruzel, Latest False Fact-Checks On William Barr, POLTICFACT (April 22, 2019), https://www.politifact.com/factchecks/list/?category=\&ruling=false\&speaker=william-barr .

J. M. Steiker, The American Death Penalty: Constitutional Regulation As the Distinctive Feature of American Exceptionalism, 67 University of Miami Law Review - U. MIAMI L. REV. (2) 329-355 (2013).

M. Fisher, Map: Which Countries Use the Death Penalty?, The AtLantic (July 6, 2011), https://www.theatlantic.com/international/archive/2011/07/map-which-countries-use-thedeath-penalty/241490/ .

R. Balko, Bad science puts innocent people in jail - and keeps them there, WASHINGTON POST -WASH. PosT. (Mar. 21, 2018), https://www.washingtonpost.com/outlook/bad-science-putsinnocent-people-in-jail--and-keeps-them-there/2018/03/20/f1fffd08-263e-11e8-b79df3d931db7f68_story.html .

R. Balko, The criminal justice system also has an 'alternative facts' problem, WASHINGTON Post -WASH. POST (Jan. https://www.washingtonpost.com/opinions/2019/01/31/criminal-justice-system-also-has-analternative-facts-problem/. 
R. E. Barnett, The Separation of People and State, 32 Harvard Journal of Law and Public Policy - HARV. J.L. \& PUB. POL'Y 451-454 (2009).

R. Morin \& David Cohen, Giuliani: 'Truth isn't truth', POLITICO (Aug. 19, 2019), https://www.politico.com/story/2018/08/19/giuliani-truth-todd-trump-788161.

R. Sinderbrand, How Kellyanne Conway ushered in the era of 'alternative facts', WASHINGTON Post - WASH. POST. (Jan. 22, 2017), https://www.washingtonpost.com/news/thefix/wp/2017/01/22/how-kellyanne-conway-ushered-in-the-era-of-alternative-facts/ .

R. S. Frase, Comparative Criminal Justice As A Guide to American Law Reform: How do the french do it, how can we find out, and why should we care?, 78 CAL. L. REV. 539, 544 (1990).

Statement of Attorney General William P. Barr on the Inspector General's Report of the Review of Four FISA Applications and Other Aspects of the FBI's Crossfire Hurricane Investigation, US DEPARTAMENT OF JUSTICE - DEP'T OF JUST (Dec. 9, 2019), https://www.justice.gov/opa/pr/statement-attorney-general-william-p-barr-inspector-generalsreport-review-four-fisa.

S. Gardbaum, The Myth and the Reality of American Constitutional Exceptionalism, 107 Michigan Law Review - MicH. L. REV. 391-466 (2008).

S. G. Calabresi, A Shining City on A Hill: American Exceptionalism and the Supreme Court's Practice of Relying on Foreign Law, 86 Boston University Law Review - B.U. L. REV. 13351416 (2006).

Treaties and Agreements, U.S. DeP'T OF STATE (Mar. 7, 2012), https://20092017.state.gov/j/inl/rls/nrcrpt/2012/vol2/184110.htm .

W. W. Berry III, American Procedural Exceptionalism: A Deterrent or A Catalyst for Death Penalty Abolition?, 17 CORnell Journal of LAW AND Public POLICY - CoRnell J.L. \& PuB. POL'Y 481-513 (2008).

\section{CASeS}

Commonwealth v. Kunko, No. 482 C 1991 (Pa. Super. Oct. 29, 2010), https://reason.com/wp-content/uploads/assets/db/13037486936458.pdf .

Commonwealth v. Ross, No. 1738 WDA 2018, 2019 WL 6211324 (Pa. Super. Ct. Nov. 21, 2019), http://www.pacourts.us/assets/opinions/Superior/out/J-S55007-19m\%20$\% 2010423159687925902 . p d f$.

Howard v. State, 945 So. 2d 326 (Miss. 2006).

Roper v. Simmons, 543 U.S. 551 (2005). 